\title{
Caustic-Side Solvent Extraction: Prediction of Cesium Extraction From Actual Wastes and Actual Waste Simulants
}

February 2003

Prepared by

Lætitia H. Delmau

Tamara J. Haverlock

Frederick V. Sloop, Jr.

Bruce A. Moyer 


\title{
DOCUMENT AVAILABILITY
}

Reports produced after January 1, 1996, are generally available free via the U.S. Department of Energy (DOE) Information Bridge:

Web site: http://www.osti.gov/bridge

Reports produced before January 1, 1996, may be purchased by members of the public from the following source:

National Technical Information Service

5285 Port Royal Road

Springfield, VA 22161

Telephone: 703-605-6000 (1-800-553-6847)

TDD: 703-487-4639

Fax: 703-605-6900

E-mail: info@ntis.fedworld.gov

Web site: http://www.ntis.gov/support/ordernowabout.htm

Reports are available to DOE employees, DOE contractors, Energy Technology Data Exchange (ETDE) representatives, and International Nuclear Information System (INIS) representatives from the following source:

Office of Scientific and Technical Information

P.O. Box 62

Oak Ridge, TN 37831

Telephone: 865-576-8401

Fax: 865-576-5728

E-mail: reports@adonis.osti.gov

Web site: http://www.osti.gov/contact.html

\begin{abstract}
This report was prepared as an account of work sponsored by an agency of the United States Government. Neither the United States government nor any agency thereof, nor any of their employees, makes any warranty, express or implied, or assumes any legal liability or responsibility for the accuracy, completeness, or usefulness of any information, apparatus, product, or process disclosed, or represents that its use would not infringe privately owned rights. Reference herein to any specific commercial product, process, or service by trade name, trademark, manufacturer, or otherwise, does not necessarily constitute or imply its endorsement, recommendation, or favoring by the United States Government or any agency thereof. The views and opinions of authors expressed herein do not necessarily state or reflect those of the United States Government or any agency thereof.
\end{abstract}


ORNL/TM-2003/011

\title{
CAUSTIC-SIDE SOLVENT EXTRACTION: PREDICTION OF CESIUM EXTRACTION FROM ACTUAL WASTES AND ACTUAL WASTE SIMULANTS
}

\author{
Lætitia H. Delmau, Tamara J. Haverlock, Frederick V. Sloop, Jr., and Bruce A. Moyer
}

Date Published: February 2003

\author{
Prepared by \\ OAK RIDGE NATIONAL LABORATORY \\ P.O. Box 2008 \\ Oak Ridge, Tennessee 37831-6285 \\ managed by \\ UT-Battelle, LLC \\ for the \\ U.S. DEPARTMENT OF ENERGY \\ under contract DE-AC05-00OR22725
}


Page intentionally left blank. 


\section{CONTENTS}

\section{Page}

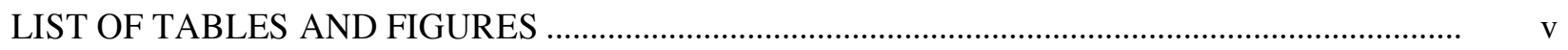

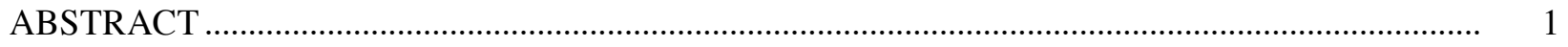

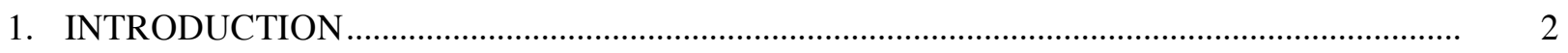

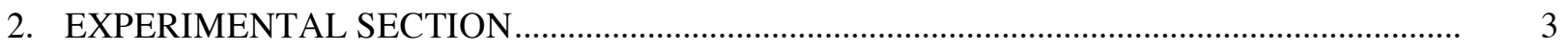

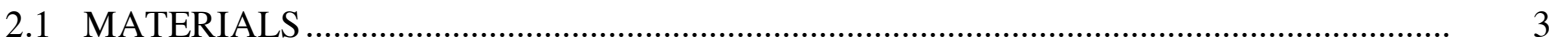

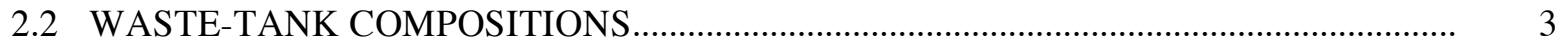

2.3 GENERAL CONTACTING AND COUNTING PROCEDURE ........................................ 5

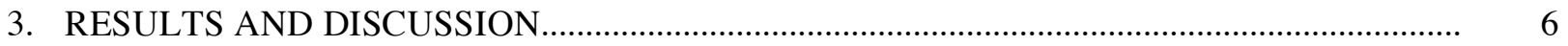

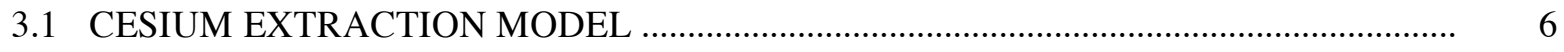

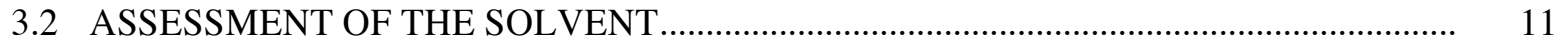

3.3 CESIUM EXTRACTION RESULTS USING THE TANK SIMULANTS ......................... 13

3.4 COMPARISON SIMULANT / ACTUAL WASTES / PREDICTION .................................. 14

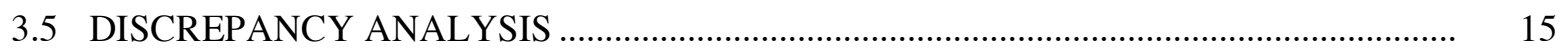

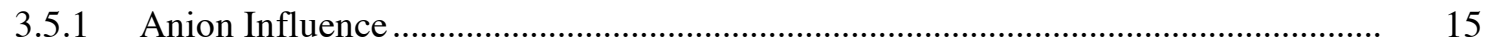

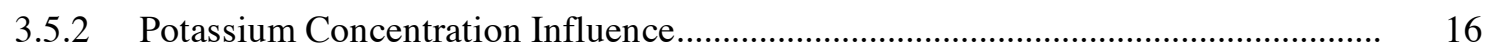

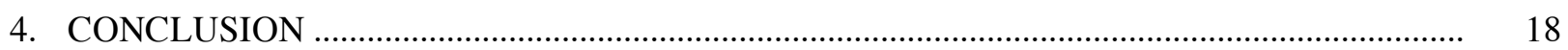

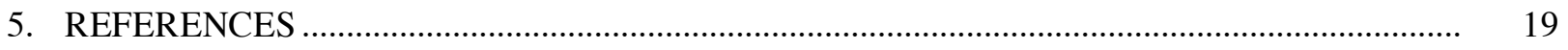

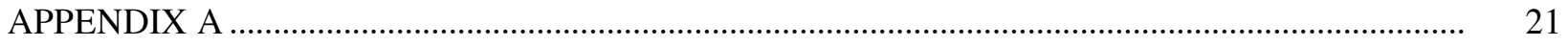


Page intentionally left blank. 


\section{LIST OF TABLES AND FIGURES}

Table

Page

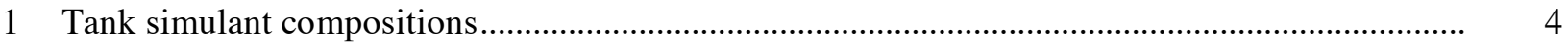

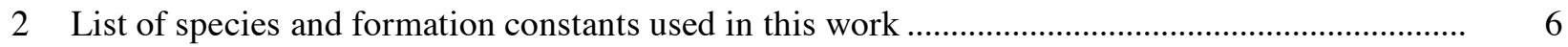

3 Molecular weights and nonaqueous molar volumes of the constituents .......................................

4 Masson coefficients of ions present in the system ......................................................................

5 Pitzer parameters for the interactions between cations and anions ............................................. 9

6 Pitzer mixing parameters for symmetrical mixing ................................................................... 10

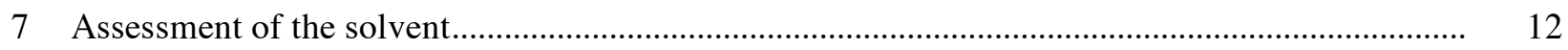

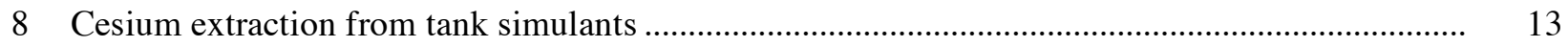

9 Comparison actual wastes, simulants, and predicted cesium distribution ratios ........................... 14

10 Influence of potassium concentration on cesium extraction performance ..................................... 17

Figure

1 Influence of aluminate/carbonate ratio in tank simulant on cesium extraction.............................. 16 
Page intentionally left blank. 


\begin{abstract}
This report presents the work that followed the CSSX model development completed in FY2002. The developed cesium and potassium extraction model was based on extraction data obtained from simple aqueous media. It was tested to ensure the validity of the prediction for the cesium extraction from actual waste. Compositions of the actual tank waste were obtained from the Savannah River Site personnel and were used to prepare defined simulants and to predict cesium distribution ratios using the model. It was therefore possible to compare the cesium distribution ratios obtained from the actual waste, the simulant, and the predicted values. It was determined that the predicted values agree with the measured values for the simulants. Predicted values also agreed, with three exceptions, with measured values for the tank wastes. Discrepancies were attributed in part to the uncertainty in the cation/anion balance in the actual waste composition, but likely more so to the uncertainty in the potassium concentration in the waste, given the demonstrated large competing effect of this metal on cesium extraction. It was demonstrated that the upper limit for the potassium concentration in the feed ought to not exceed $0.05 \mathrm{M}$ in order to maintain suitable cesium distribution ratios.
\end{abstract}




\section{INTRODUCTION}

An improved understanding of the CSSX process, chosen by U.S. Department of Energy for cesium removal from the alkaline high-level waste stored at the Savannah River Site (SRS), was demonstrated in FY2002 by establishing a model [1] that predicts the extraction of cesium and its chief competing cation, potassium, from alkaline tank wastes (or simulants) using the optimized CSSX solvent [2]. Following a modeling study that was initiated in FY2001 based on the earlier solvent system [3], the new model was developed by modeling extraction systems of increasing complexity, using either single salts or mixtures of up to four sodium salts. Tests of the model were performed in FY2002 by comparing predicted and experimental cesium distribution ratios for simplified simulants of the wastes in five different tanks. Satisfactory agreement was found between predicted and experimental results using simulated wastes.

The purpose of the present work is to establish the reliability and potential weaknesses of the current model by comparing the predicted values of cesium distribution from characterized actual wastes and the actual values measured by SRS personnel. In order to determine the origin of any discrepancies observed between the two results, simulants were prepared based on characterization data and used to obtain cesium distribution ratios from solutions of defined composition.

The model specifically takes into account cesium, potassium, and sodium extraction through complexes formed with nitrate, nitrite, hydroxide, and chloride. Although the model includes aluminate, sulfate, carbonate, phosphate, formate, and fluoride as aqueous constituents, these species are not included in any of the organic-phase complexes assumed to be formed. Thus, these species participate only indirectly (through activity effects) in the extraction process.

The first step of the study was to check the integrity of the solvent and repeat some of the cesium extractions from simple aqueous solutions. The robustness of the solvent having been demonstrated previously [4], no changes were expected. The following experiments involved the preparation and the testing of the simulants containing all the elements present in the SRS recommended compositions. Seven different simulants were tested. In the event that any discrepancies between the results for a waste and its simulant might be discovered, it was planned to prepare and test additional simulants to try to explain the disagreement. Predictions for a range of selected conditions were also obtained to highlight the influence of given system components on extraction behavior. 


\section{EXPERIMENTAL SECTION}

\subsection{MATERIALS}

Simulants and stock solutions of single salts were prepared directly from ACS (American Chemical Society)-grade reagents. Sodium hydroxide (EM Science, Lot No. 126754-115657) was prepared by dissolving weighed quantities of $\mathrm{NaOH}$ pellets in nanopure water. Sodium chloride was received from EM Science (EM Sci.), Lot No. 33131325; $\mathrm{NaNO}_{2}$ was received from J. T. Baker, Lot No. L32624; $\mathrm{NaNO}_{3}$ was received from EM Sci., Lot 40074121, as reagent-grade crystalline material. Cesium chloride, 99.999\% purity, was purchased from International Biotechnologies, Inc. (Lot No. 0F0751). Cesium fluoride, 99.99\% purity was supplied by Aldrich Chemical Co. (Aldrich). The nitrate (Lot No. 07319DU), hydroxide (Lot No. 0643KU), carbonate (Lot No. ES 04403BS), and sulfate (Lot No. 02922M) salts of cesium were also purchased from Aldrich. Potassium nitrate, $99.99 \%$ purity, was received from Aldrich (Lot No. 1242AO); the chloride salt was supplied by EM Science, Lot No. 6116. Potassium nitrite solutions were derived from reagent-grade salt manufactured by Mallinkrodt Chemical Works (Mallinkrodt), Lot KHXH. Pellets of potassium hydroxide, with a stated moisture content of less than $14 \%$, were supplied by Fluka Biochemika. Cesium and potassium salts were added at $0.5 \mathrm{mM}$ and $60 \mathrm{mM}$, respectively, directly to the previously prepared sodium salt solutions, effecting a slight dilution $(<1 \%)$ of the initial sodium in solution. The organic phase consisted of 0.007 M BOBCalixC6 (Lot No. 00714MKC-004); 0.750 M Cs-7SB (1-(2,2,3,3-tetrafluoropropoxy)-3-(4-sec-butylphenoxy)-2-propanol) modifier (Lot No. B00894-64DM); 0.003 M tri-n-octylamine (Lot No. B00894-86); and Isopar® L (Lot No. 03081001-6-2) prepared by P. V. Bonnesen and K. Anderson at ORNL on December 3, 2001. The radiotracer ${ }^{137} \mathrm{Cs}$ was obtained from Isotope Products, Burbank, CA. An $80 \mu \mathrm{Ci} / \mathrm{mL}$ cesium tracer working stock containing $4 \mathrm{mM} \mathrm{HCl}$ was prepared. The simulant $(120 \mathrm{~mL})$ was spiked with $300 \mu \mathrm{L}$ of this working stock to get a ${ }^{137} \mathrm{Cs}$ activity of approximately $0.20 \mu \mathrm{Ci} / \mathrm{mL}$.

\subsection{WASTE TANK COMPOSITIONS}

The composition of each tank simulant is given in Table 1. These differ slightly from the previously reported actual tank waste compositions and modeling predictions [5]. For modeling purposes, the cation/anion balance is achieved by modifying slightly the aluminate concentration. Two tank compositions, labeled as $41 \mathrm{H}$ and "Pre-permanganate treatment," were communicated after the tests with the simulants were completed, mostly to compare the results obtained with the actual wastes and the predicted values. They are included in Table 1, since they are used subsequently in the modeling section. 
Table 1. Tank simulant compositions

\begin{tabular}{|c|c|c|c|c|c|c|c|c|c|c|c|c|c|c|}
\hline Tank & {$\left[\mathrm{Na}^{+}\right]$} & {$\left[\mathrm{K}^{+}\right]$} & {$\left[\mathrm{Cs}^{+}\right]$} & {$\left[\mathrm{NO}_{3}{ }^{-}\right]$} & {$\left[\mathrm{Cl}^{-}\right]$} & {$\left[\mathrm{NO}_{2}^{-}\right]$} & {$\left[\mathrm{OH}^{-}\right]$} & {$\left[\mathrm{F}^{-}\right]$} & [Formate] & {$\left[\mathrm{PO}_{4}{ }^{3-}\right]$} & {$\left[\mathrm{SO}_{4}{ }^{2-}\right]$} & {$\left[\mathrm{CO}_{3}{ }^{2-}\right]$} & {$\left[\mathrm{AlO}_{4}^{-}\right]$} & {$\left[\mathrm{AlO}_{4}{ }^{-}\right]_{\mathrm{corr}}$} \\
\hline $26 \mathrm{~F}$ & 5.60 & $3.0 \times 10^{-2}$ & $2.9 \times 10^{-5}$ & $9.96 \times 10^{-1}$ & $6.3 \times 10^{-3}$ & $4.4 \times 10^{-1}$ & 3.68 & $1.3 \times 10^{-2}$ & $2.15 \times 10^{-2}$ & $3.9 \times 10^{-3}$ & $3.0 \times 10^{-2}$ & $8.00 \times 10^{-2}$ & 0.25 & $2.37 \times 10^{-1}$ \\
\hline $34 \mathrm{~F}$ & 5.80 & $4.0 \times 10^{-2}$ & $2.9 \times 10^{-5}$ & 1.14 & $5.6 \times 10^{-3}$ & $6.4 \times 10^{-1}$ & 3.60 & 0.0 & $5.30 \times 10^{-3}$ & $2.8 \times 10^{-3}$ & $1.0 \times 10^{-2}$ & $7.00 \times 10^{-2}$ & 0.28 & $2.81 \times 10^{-1}$ \\
\hline $46 \mathrm{~F}$ & 5.79 & $3.0 \times 10^{-2}$ & $2.9 \times 10^{-5}$ & 1.12 & $5.7 \times 10^{-3}$ & $6.2 \times 10^{-1}$ & 3.60 & $4.0 \times 10^{-3}$ & $3.58 \times 10^{-2}$ & $3.4 \times 10^{-3}$ & $1.0 \times 10^{-2}$ & $8.00 \times 10^{-2}$ & 0.28 & $2.44 \times 10^{-1}$ \\
\hline $30 \mathrm{H}$ & 5.73 & $4.0 \times 10^{-2}$ & $1.24 \times 10^{-4}$ & $6.45 \times 10^{-1}$ & $4.4 \times 10^{-3}$ & $6.5 \times 10^{-1}$ & 3.90 & 0.0 & 0.0 & $5.0 \times 10^{-3}$ & $4.0 \times 10^{-3}$ & $1.72 \times 10^{-1}$ & 0.40 & $2.03 \times 10^{-1}$ \\
\hline $32 \mathrm{H}$ & 5.70 & $3.0 \times 10^{-2}$ & $1.3 \times 10^{-4}$ & 1.20 & $1.4 \times 10^{-3}$ & $8.0 \times 10^{-1}$ & 3.05 & 0.0 & 0.0 & $3.1 \times 10^{-3}$ & $2.0 \times 10^{-2}$ & $1.22 \times 10^{-1}$ & 0.50 & $3.90 \times 10^{-1}$ \\
\hline Post $\mathrm{MnO}_{4}$ & 5.60 & $5.9 \times 10^{-2}$ & $3.2 \times 10^{-5}$ & $8.64 \times 10^{-1}$ & $8.3 \times 10^{-3}$ & $7.0 \times 10^{-1}$ & 3.60 & 0.0 & 0.0 & $6.2 \times 10^{-3}$ & $4.0 \times 10^{-3}$ & $9.50 \times 10^{-2}$ & 0.30 & $2.70 \times 10^{-1}$ \\
\hline $37 \mathrm{H} \mathrm{SC}^{*}$ & 6.20 & $5.9 \times 10^{-2}$ & $3.4 \times 10^{-4}$ & $8.40 \times 10^{-1}$ & $9.0 \times 10^{-3}$ & $7.0 \times 10^{-1}$ & 3.90 & 0.0 & 0.0 & $2.0 \times 10^{-2}$ & $5.0 \times 10^{-3}$ & $2.37 \times 10^{-1}$ & 0.54 & $2.67 \times 10^{-1}$ \\
\hline $41 \mathrm{H}$ & 5.13 & $4.0 \times 10^{-2}$ & $1.7 \times 10^{-4}$ & 3.28 & 0.0 & $1.7 \times 10^{-1}$ & $60 \times 10^{-1}$ & 0.0 & 0.0 & $2.0 \times 10^{-3}$ & $4.0 \times 10^{-2}$ & $4.10 \times 10^{-1}$ & 0.16 & $1.54 \times 10^{-1}$ \\
\hline Pre $\mathrm{MnO}_{4}$ & 5.20 & $5.0 \times 10^{-3}$ & $4.0 \times 10^{-5}$ & $6.10 \times 10^{-1}$ & 0.0 & $5.1 \times 10^{-1}$ & 3.29 & 0.0 & 0.0 & $2.0 \times 10^{-3}$ & $1.0 \times 10^{-2}$ & $1.50 \times 10^{-1}$ & 0.47 & $4.79 \times 10^{-1}$ \\
\hline
\end{tabular}

*The SC abbreviation stands for "saltcake"

All concentrations are in $\mathrm{mol} / \mathrm{L}$.

The grayed column contains the original values of aluminate concentrations given by SRS personnel. The column entitled [AlO ${ }_{4}^{-}$ ]$_{\text {corr }}$ contains the concentrations of aluminate corrected to balance the total cations/anions concentrations. 


\subsection{GENERAL SOLVENT EXTRACTION AND COUNTING PROCEDURE}

Capped polypropylene micro-tubes were mounted by clips on a disk that was rotated in a constant-temperature air box at $25.0 \pm 0.5^{\circ} \mathrm{C}$ for 30 minutes. After the contacting period, the tubes were centrifuged for 3 minutes at $3000 \mathrm{RPM}$ and $25{ }^{\circ} \mathrm{C}$ in a Beckman Coulter ${ }^{\mathrm{TM}}$ Allegra 6R temperaturecontrolled centrifuge. A $300 \mu \mathrm{L}$ aliquot of each phase was subsampled and counted using a Packard Cobra II Auto-Gamma counter. Aqueous phases were counted for a period of 5 minutes; organic phases were counted for 10 minutes using a window of $580-750 \mathrm{keV}$. 


\section{RESULTS AND DISCUSSION}

\subsection{CESIUM EXTRACTION MODEL}

This section presents all the parameters, refined and not refined, that are used by the computer program SXFIT to predict cesium extraction performance from an aqueous solution with a given composition. Table 2 presents the organic-phase species used in FY2002 to model the extraction of cesium, potassium, and sodium. The following Tables 2-6 contain the data necessary to the model. These data are tabulated and available in the literature. For further details on the program, the reader is referred to the report published previously [1].

Table 2. List of species and formation constants used in this work

\begin{tabular}{|c|c|}
\hline Species & $\begin{array}{l}\text { Formation constant } \\
\qquad \log _{10} K\end{array}$ \\
\hline $\mathrm{CsNO}_{3} \mathrm{Calix}(\mathrm{o})$ & $3.656 \pm 0.029$ \\
\hline$\left(\mathrm{CsNO}_{3}\right)_{2} \mathrm{Calix}(\mathrm{o})$ & $7.681 \pm 0.084$ \\
\hline CsOHCalix(o) & $3.292 \pm 0.016$ \\
\hline $\mathrm{CsNO}_{2} \mathrm{Calix}(\mathrm{o})$ & $3.166 \pm 0.013$ \\
\hline CsClCalix(o) & $2.709 \pm 0.013$ \\
\hline $\mathrm{KNO}_{3}$ Calix(o) & $1.427 \pm 0.016$ \\
\hline KOHCalix(o) & $1.385 \pm 0.017$ \\
\hline $\mathrm{KNO}_{2} \operatorname{Calix}(\mathrm{o})$ & $1.135 \pm 0.015$ \\
\hline KClCalix(o) & $0.649 \pm 0.014$ \\
\hline $\mathrm{NaOH}(\mathrm{o})$ & $-0.805 \pm 0.036$ \\
\hline $\mathrm{NaNO}_{3} \mathrm{Calix}(\mathrm{o})$ & $-0.803 \pm 0.041$ \\
\hline $\mathrm{NaNO}_{2} \mathrm{Calix}(\mathrm{o})$ & $-0.892 \pm 0.024$ \\
\hline NaClCalix(o) & $-1.250 \pm 0.025$ \\
\hline
\end{tabular}

(o) indicates the presence a species in the organic phase. As can be seen, all product species assumed to be formed during extraction are in the organic phase.

The formation constants of the predominant species $\mathrm{CsNO}_{3}$ Calix and CsOHCalix were slightly modified (respectively 3.656 instead of 3.591 and 3.292 instead of 3.357) after careful re-examination of all the 
data obtained in FY2002 and use of updated values of Masson coefficients and Pitzer parameters (see below).

Table 3. Molecular weights and nonaqueous molar volumes of the constituents

\begin{tabular}{|c|c|c|}
\hline Constituent & Formula Weight $(\mathrm{g} / \mathrm{mol})$ & $\begin{array}{l}\text { Nonaqueous molar volume } \\
\qquad\left(\mathrm{cm}^{3} / \mathrm{mol}\right)^{*}\end{array}$ \\
\hline $\mathrm{Na}^{+}$ & 22.990 & 10 \\
\hline $\mathrm{K}^{+}$ & 39.098 & 9 \\
\hline $\mathrm{Cs}^{+}$ & 132.91 & 21.5 \\
\hline $\mathrm{H}^{+}$ & 1.008 & 0 \\
\hline $\mathrm{NO}_{3}^{-}$ & 62.005 & 29 \\
\hline $\mathrm{Cl}^{-}$ & 35.450 & 18 \\
\hline $\mathrm{NO}_{2}^{-}$ & 46.006 & 26 \\
\hline $\mathrm{OH}^{-}$ & 17.008 & 18 \\
\hline $\mathrm{CO}_{3}{ }^{2-}$ & 59.997 & -3.7 \\
\hline $\mathrm{SO}_{4}^{2-}$ & 95.996 & 14.3 \\
\hline $\mathrm{F}^{-}$ & 18.998 & -1.0 \\
\hline Formate & 45.018 & 34 \\
\hline $\mathrm{Al}(\mathrm{OH})_{4}^{-}$ & 90.979 & 14 \\
\hline $\mathrm{PO}_{4}{ }^{3-}$ & 94.971 & 10 \\
\hline BOBCalixC6 & 1149.53 & 500 \\
\hline Diluent (Isopar ${ }^{\circledR}$ L) & 170 & 227 \\
\hline Water & & 18 \\
\hline
\end{tabular}

*The values for the ions are based on their aqueous molar volumes $\mathrm{V}_{0}$ presented in Table 4 . The value for sodium is a personal communication from Charles F. Baes, Jr.

The values for the constituents and product species presented in Tables 2-6 are those called by the program and changeable by the users. The molecular weight of water is $18.015 \mathrm{~g} / \mathrm{mol}$. This value is a constant. 
Table 4. Masson coefficients [6] of ions present in the system

\begin{tabular}{l||c||c}
\hline Constituent & $\mathbf{V}_{\mathbf{0}}$ & $\mathbf{S v}$ \\
\hline $\mathrm{Na}^{+}$ & -1.3 & 1.203 \\
$\mathrm{~K}^{+}$ & 8.73 & 1.10 \\
$\mathrm{Cs}^{+}$ & 21.40 & 1.29 \\
$\mathrm{H}^{+}$ & 0 & 0 \\
$\mathrm{NO}_{3}^{-}$ & 29.33 & 0.543 \\
$\mathrm{Cl}^{-}$ & 18.12 & 0.83 \\
$\mathrm{NO}_{2}^{-}$ & 26.5 & 2.00 \\
$\mathrm{OH}^{-}$ & -4.04 & 2.32 \\
$\mathrm{CO}_{3}{ }^{2-}$ & -3.7 & 7.30 \\
$\mathrm{SO}_{4}{ }^{2-}$ & 14.3 & 10.50 \\
$\mathrm{Al}^{-}(\mathrm{OH})_{4}^{-}$ & 30.0 & 1.0 \\
$\mathrm{PO}_{4}{ }^{3-}$ & 5.0 & 10.0 \\
$\mathrm{Formate}^{-}$ & 26.5 & 0.50 \\
$\mathrm{~F}^{-}$ & -0.85 & 1.35 \\
\hline
\end{tabular}


Table 5. Pitzer parameters [7],[8] for the interactions between cations and anions

\begin{tabular}{|c|c|c|c|}
\hline Interaction & $\beta_{0}$ & $\beta_{1}$ & $\mathrm{C}_{\Phi}$ \\
\hline $\mathrm{H}^{+}-\mathrm{NO}_{3}^{-}$ & 0.11190 & 0.36860 & 0.002470 \\
\hline $\mathrm{Na}^{+}-\mathrm{NO}_{3}^{-}$ & 0.006800 & 0.1783 & -0.000720 \\
\hline $\mathrm{Na}^{+}-\mathrm{Cl}^{-}$ & 0.07650 & 0.26640 & 0.001270 \\
\hline $\mathrm{Na}^{+}-\mathrm{NO}_{2}^{-}$ & 0.06410 & 0.10150 & -0.004900 \\
\hline $\mathrm{Na}^{+}-\mathrm{OH}^{-}$ & 0.08640 & 0.25300 & 0.004000 \\
\hline $\mathrm{Na}^{+}-\mathrm{F}^{-}$ & 0.0215 & 0.2107 & 0.000000 \\
\hline $\mathrm{Na}^{+}-\mathrm{SO}_{4}{ }^{2-}$ & 0.01958 & 1.11300 & 0.002487 \\
\hline $\mathrm{Na}^{+}-\mathrm{CO}_{3}{ }^{2-}$ & 0.03623 & 1.50975 & 0.002599 \\
\hline $\mathrm{Na}^{+}$-Formate & 0.08200 & 0.28720 & -0.00523 \\
\hline $\mathrm{Na}^{+}-\mathrm{Al}(\mathrm{OH})_{4}^{-}$ & 0.05100 & 0.25000 & -0.00090 \\
\hline $\mathrm{Na}^{+}-\mathrm{PO}_{4}{ }^{3-}$ & 0.17813 & 3.85133 & -0.05153 \\
\hline $\mathrm{K}^{+}-\mathrm{NO}_{3}^{-}$ & -0.08160 & 0.04940 & 0.006600 \\
\hline $\mathrm{K}^{+}-\mathrm{Cl}^{-}$ & 0.04835 & 0.21220 & -0.000840 \\
\hline $\mathrm{K}^{+}-\mathrm{NO}_{2}^{-}$ & 0.01510 & 0.01500 & 0.000700 \\
\hline $\mathrm{K}^{+}-\mathrm{OH}^{-}$ & 0.12980 & 0.32000 & 0.000410 \\
\hline $\mathrm{K}^{+}-\mathrm{F}^{-}$ & 0.080890 & 0.20210 & 0.000930 \\
\hline $\mathrm{K}^{+}$-Formate & 0.100000 & 0.30000 & -0.00500 \\
\hline $\mathrm{K}^{+}-\mathrm{Al}(\mathrm{OH})_{4}^{-}$ & 0.05100 & 0.25000 & -0.00090 \\
\hline $\mathrm{K}^{+}-\mathrm{SO}_{4}^{2-}$ & 0.049950 & 0.77925 & 0.000000 \\
\hline $\mathrm{K}^{+}-\mathrm{CO}_{3}{ }^{2-}$ & 0.128775 & 1.433250 & 0.000000 \\
\hline $\mathrm{K}^{+}-\mathrm{PO}_{4}^{3-}$ & 0.372933 & 3.97200 & -0.086795 \\
\hline $\mathrm{Cs}^{+}-\mathrm{NO}_{3}^{-}$ & -0.07580 & -0.06690 & 0.000000 \\
\hline $\mathrm{Cs}^{+}-\mathrm{Cl}^{-}$ & 0.03478 & 0.03974 & -0.000496 \\
\hline $\mathrm{Cs}^{+}-\mathrm{NO}_{2}{ }^{-}$ & 0.04270 & 0.06000 & -0.005100 \\
\hline $\mathrm{Cs}^{+}-\mathrm{OH}^{-}$ & 0.15000 & 0.30000 & 0.000000 \\
\hline $\mathrm{Cs}^{+}-\mathrm{F}^{-}$ & 0.13060 & 0.25700 & -0.00430 \\
\hline $\mathrm{Cs}^{+}-\mathrm{SO}_{4}{ }^{2-}$ & 0.07140 & 1.20075 & 0.001456 \\
\hline $\mathrm{Cs}^{+}$-Formate & 0.10000 & 0.30000 & -0.00500 \\
\hline $\mathrm{Cs}^{+}-\mathrm{Al}(\mathrm{OH})_{4}^{-}$ & 0.05100 & 0.25000 & -0.00090 \\
\hline $\mathrm{Cs}^{+}-\mathrm{PO}_{4}^{3-}$ & 0.372933 & 3.97200 & -0.086795 \\
\hline $\mathrm{Cs}^{+}-\mathrm{CO}_{3}{ }^{2-}$ & 0.03623 & 1.50975 & 0.002599 \\
\hline
\end{tabular}


All $\beta_{2}$ values are set to 0 . Parameter $\alpha_{1}=2$, and $\alpha_{2}=0$, since all the interactions are between two monocharged ions.

Table 6. Pitzer mixing parameters [7],[9] for symmetrical mixing

\begin{tabular}{l||c||c}
\hline Interaction & $\mathbf{1 0} \boldsymbol{\Theta}$ & $\mathbf{1 0} \boldsymbol{\Psi}$ \\
\hline $\mathrm{Na}^{+}-\mathrm{NO}_{3}{ }^{-}-\mathrm{Cl}^{-}$ & 2.26 & -0.72 \\
$\mathrm{Na}^{+}-\mathrm{Cl}^{-}-\mathrm{OH}^{-}$ & -7.0 & -0.32 \\
$\mathrm{Na}^{+}-\mathrm{K}^{+}-\mathrm{NO}_{3}^{-}$ & -2.13 & 0.09 \\
$\mathrm{Na}^{+}-\mathrm{OH}^{-} \mathrm{Al}(\mathrm{OH})_{4}^{-}$ & 1.4 & -0.48 \\
$\mathrm{~K}^{+}-\mathrm{Cl}^{-}-\mathrm{OH}^{-}$ & -7.0 & 0.16 \\
$\mathrm{~K}^{+}-\mathrm{Cl}^{-}-\mathrm{NO}_{3}^{-}$ & 2.26 & -0.77 \\
$\mathrm{~K}^{+}-\mathrm{Cs}^{+}-\mathrm{Cl}^{-}$ & -0.37 & -0.06 \\
\hline
\end{tabular}

Regarding the activity coefficients in the organic phase, all the product species were assigned a similar value. The solubility parameter of the diluent (Isopar ${ }^{\circledR}$ L) and the extractant BOBCalixC6 were determined by group-contribution calculations [10]. The calixarene solubility parameter was estimated with the group contributions and determined to be $21 \mathrm{~J}^{1 / 2} \mathrm{~cm}^{-3 / 2}$. All organic species formed in the organic phase were assigned a solubility parameter of $19.8 \mathrm{~J}^{1 / 2} \mathrm{~cm}^{-3 / 2}$, which is also the solubility parameter of the modifier. Previous studies showed that at least one molecule of modifier was included in the complexes, and the solubility parameter is close enough to the value for the calixarene to avoid any major activity effect. Since the modifier itself is not included as a component of the system, the solubility parameter of the mixture of Isopar ${ }^{\circledR} \mathrm{L}$ and modifier is set at $18.8 \mathrm{~J}^{1 / 2} \mathrm{~cm}^{-3 / 2}$ (respective weighing factor applied to their solubility parameters based on their relative proportion in the solvent). While solubility parameters give a more realistic view of the behavior in the organic phase, they do not have a crucial effect on the final results, as the mole fraction of extracted species in the solvent is very small. This hypothesis was verified by assuming ideality in the organic phase. The formation constants of all organic product species varied minimally (within the error associated with the $\log _{10} K$ value, see Table 2). Assuming ideality in the organic phase is therefore validated for the process model; however, solubility parameters are provided for information purposes to maintain the option of nonideality in more rigorous alternative treatment.

The dielectric constant of the diluent equals 2.014 [11]; the diluent solubility parameter is set to $18.40 \mathrm{~J}^{1 / 2} \mathrm{~cm}^{-3 / 2}$. The dielectric constant is used in the model to calculate the formation constant of dissociated species (charged species) in the organic phase (see section 4.1.5). The dielectric constant of the diluent is low (consistent for an alkane-based diluent), but probably does not represent properly the polarity of the solvent after addition of the modifier at $0.75 \mathrm{M}$. The value of the dielectric constant as a 
parameter was increased to 12 , which represents the contribution from an alcohol to the alkane diluent [11] and used in the model. The solubility parameter of water is set to $51.13 \mathrm{~J}^{1 / 2} \mathrm{~cm}^{-3 / 2}$ [12].

\subsection{ASSESSMENT OF THE SOLVENT}

This preliminary section is to serve as a check on the results obtained in FY2002 [1] to confirm that the performance of the solvent is still identical to that observed in FY2002 that permitted the determination of the model. Thirteen data points from the original studies were selected arbitrarily to be repeated in this exercise. From the single sodium salt media were selected $0.5 \mathrm{M} \mathrm{NaNO}_{3}, 0.5 \mathrm{M} \mathrm{NaOH}$, $0.5 \mathrm{M} \mathrm{NaNO}_{2}$, and $0.5 \mathrm{M} \mathrm{NaCl}$, each also containing $5 \times 10^{-4} \mathrm{M} \mathrm{CsNO}_{3}$. From systems that contained a mixture of two sodium salts six points were selected including, 2.5 $\mathrm{M} \mathrm{NaNO}_{3} / 2.5 \mathrm{M} \mathrm{NaCl}, 2.5 \mathrm{M}$ $\mathrm{NaNO}_{3} / 2.5 \mathrm{M} \mathrm{NaNO}_{2}, 2.5 \mathrm{M} \mathrm{NaNO}_{3} / 2.5 \mathrm{M} \mathrm{NaOH}, 2.5 \mathrm{M} \mathrm{NaCl} / 2.5 \mathrm{M} \mathrm{NaNO}_{2}, 2.5 \mathrm{M} \mathrm{NaCl} / 2.5 \mathrm{M}$ $\mathrm{NaOH}$, and $2.5 \mathrm{M} \mathrm{NaNO}_{2} / 2.5 \mathrm{M} \mathrm{NaOH}-$ all containing $5 \times 10^{-4} \mathrm{M} \mathrm{CsNO}_{3}$. From those systems that contained a mixture of three or four sodium salts the following were selected for repeating: a) $1 \mathrm{M} \mathrm{NaCl} /$ $2 \mathrm{M} \mathrm{NaNO}_{3} / 2.6 \mathrm{M} \mathrm{NaOH}$, b) $2 \mathrm{M} \mathrm{NaCl} / 1.5 \mathrm{M} \mathrm{NaNO}_{3} / 2.1 \mathrm{M} \mathrm{NaOH}$, and c) $1 \mathrm{M} \mathrm{NaCl} / 1 \mathrm{M} \mathrm{NaNO}_{2} /$ $2.2 \mathrm{M} \mathrm{NaNO}_{3} / 1.4 \mathrm{M} \mathrm{NaOH}$. Each of these salt mixtures also contained $5 \times 10^{-4} \mathrm{M} \mathrm{CsNO}_{3}$. Results are presented in Table 7. 
Table 7. Assessment of the solvent.

\begin{tabular}{|c|c|c|c|c|}
\hline \multirow{2}{*}{$\begin{array}{l}\text { Aqueous Solutions } \\
\text { Salt Media - each also contains } \\
5 \times 10^{-4} \mathrm{M} \mathrm{CsNO}_{3}\end{array}$} & \multicolumn{4}{|c|}{ Cesium Distribution Ratios } \\
\hline & $D_{\mathrm{Cs}}$ & $D_{\mathrm{Cs}}(\mathrm{dupl}$.) & Average $D_{\mathrm{Cs}}$ & $\begin{array}{c}D_{\mathrm{Cs}}(\mathrm{FY} 2002 \\
\text { results })\end{array}$ \\
\hline \multicolumn{5}{|l|}{ Single Sodium Salt } \\
\hline $0.5 \mathrm{M}\left[\mathrm{NaNO}_{3}\right]_{\mathrm{init}}$ & 5.88 & 5.53 & 5.71 & 5.55 \\
\hline $0.5 \mathrm{M}[\mathrm{NaOH}]_{\text {init }}$ & 3.63 & 3.68 & 3.66 & 3.52 \\
\hline $0.5 \mathrm{M}\left[\mathrm{NaNO}_{2}\right]_{\text {init }}$ & 1.88 & 1.86 & 1.87 & 1.96 \\
\hline $0.5 \mathrm{M}[\mathrm{NaCl}]_{\text {init }}$ & 0.714 & 0.709 & 0.711 & 0.680 \\
\hline \multicolumn{5}{|l|}{ Two Sodium Salts } \\
\hline $2.5 \mathrm{M}\left[\mathrm{NaNO}_{3}\right]$ & 6.30 & 6.27 & 6.29 & 6.34 \\
\hline \multicolumn{5}{|l|}{$2.5 \mathrm{M}[\mathrm{NaCl}]$} \\
\hline $2.5 \mathrm{M}\left[\mathrm{NaNO}_{3}\right]$ & 6.24 & 6.23 & 6.24 & 7.36 \\
\hline \multicolumn{5}{|l|}{$2.5 \mathrm{M}\left[\mathrm{NaNO}_{2}\right]$} \\
\hline $2.5 \mathrm{M}\left[\mathrm{NaNO}_{3}\right]$ & 16.3 & 16.4 & 16.3 & 16.9 \\
\hline \multicolumn{5}{|l|}{$2.5 \mathrm{M}[\mathrm{NaOH}]$} \\
\hline $2.5 \mathrm{M}[\mathrm{NaCl}]$ & 5.42 & 5.73 & 5.57 & 5.35 \\
\hline \multicolumn{5}{|l|}{$2.5 \mathrm{M}\left[\mathrm{NaNO}_{2}\right]$} \\
\hline $2.5 \mathrm{M}[\mathrm{NaCl}]$ & 14.52 & 15.33 & 14.9 & 14.5 \\
\hline \multicolumn{5}{|l|}{$2.5 \mathrm{M}[\mathrm{NaOH}]$} \\
\hline $2.5 \mathrm{M}\left[\mathrm{NaNO}_{2}\right]$ & 19.3 & 19.4 & 19.4 & 18.9 \\
\hline \multicolumn{5}{|l|}{$2.5 \mathrm{M}[\mathrm{NaOH}]$} \\
\hline \multicolumn{5}{|l|}{3 or 4 Sodium Salts } \\
\hline $1 \mathrm{M}[\mathrm{NaCl}]$ & 17.3 & 17.2 & 17.2 & 17.8 \\
\hline \multicolumn{5}{|l|}{$2 \mathrm{M}\left[\mathrm{NaNO}_{3}\right]$} \\
\hline \multicolumn{5}{|l|}{$2.6 \mathrm{M}[\mathrm{NaOH}]$} \\
\hline $2 \mathrm{M}\left[\mathrm{NaNO}_{2}\right]$ & 15.4 & 15.3 & 15.3 & 15.1 \\
\hline \multicolumn{5}{|l|}{$1.5 \mathrm{M}\left[\mathrm{NaNO}_{3}\right]$} \\
\hline \multicolumn{5}{|l|}{$2.1 \mathrm{M}[\mathrm{NaOH}]$} \\
\hline $1 \mathrm{M}[\mathrm{NaCl}]$ & 10.5 & 10.9 & 10.7 & 10.6 \\
\hline \multicolumn{5}{|l|}{$1 \mathrm{M}\left[\mathrm{NaNO}_{2}\right]$} \\
\hline \multicolumn{5}{|l|}{$2.2 \mathrm{M}\left[\mathrm{NaNO}_{3}\right]$} \\
\hline $1.4 \mathrm{M}[\mathrm{NaOH}]$ & & & & \\
\hline
\end{tabular}


All results are similar to those obtained in FY2002. The model obtained in FY2002 with this solvent can therefore be used to model the data obtained with the tank-waste simulants.

\subsection{CESIUM EXTRACTION RESULTS USING THE TANK SIMULANTS}

Tank simulants have a two-fold role: first, they permit the cesium distribution ratios to be determined from a well-defined system, and second, they reveal the potential differences in extraction that may occur between actual and simulated wastes. The experimental results obtained with seven different compositions are presented in Table 8.

Table 8. Cesium extraction from tank simulants.

\begin{tabular}{lccc}
\hline Aqueous Phase & \multicolumn{3}{c}{ Cesium Distribution (Experimental Values) } \\
\hline Simulant & $D_{\mathrm{Cs}}$ & $D_{\mathrm{Cs}}$ duplicate & Average $D_{\mathrm{Cs}}$ \\
\hline Tank 26F & 13.6 & 13.4 & 13.5 \\
Tank 34F & 11.0 & 10.7 & 10.9 \\
Tank 46F & 13.4 & 12.8 & 13.1 \\
Tank 30H & 11.0 & 11.1 & 11.1 \\
Tank 32H & 11.2 & 11.9 & 11.5 \\
Post $\mathrm{MnO}_{4}$ & 8.23 & 8.05 & 8.14 \\
Tank 37H SC & 7.61 & 7.75 & 7.68 \\
\hline
\end{tabular}

Cesium distribution ratios are in the expected range, with a notable decrease for the last two tank simulants. This decrease can be attributed to the high level of potassium. This issue will be discussed in section 3.5.2. 


\subsection{COMPARISON SIMULANT / ACTUAL WASTES / PREDICTION}

All the results obtained with the actual wastes, the simulants and predicted with the model are presented in Table 9.

Table 9. Comparison actual wastes, simulants, and predicted cesium distribution ratios.

\begin{tabular}{|c|c|c|c|}
\hline Simulant & $\begin{array}{l}\text { Measured } D_{\mathrm{Cs}} \\
\text { Actual waste }\end{array}$ & $\begin{array}{l}\text { Measured } D_{\mathrm{Cs}} \\
\text { Waste simulant }\end{array}$ & Predicted $D_{\mathrm{Cs}}$ \\
\hline Tank 26F & 12.7 & 13.5 & 13.4 \\
\hline Tank 34F & 11.3 & 10.9 & 11.0 \\
\hline Tank 46F & 12.4 & 13.1 & 13.0 \\
\hline Tank $30 \mathrm{H}$ & 11.1 & 11.1 & 11.2 \\
\hline Tank $32 \mathrm{H}$ & 9.7 & 11.5 & 11.9 \\
\hline *Post $\mathrm{MnO}_{4}$ & 8.6 & 8.14 & 8.43 \\
\hline *Tank 37H SC & 9.0 & 7.68 & 8.26 \\
\hline $41 \mathrm{H}$ & 10.2 & & 6.60 \\
\hline Pre $\mathrm{MnO}_{4}$ & 10.9 & & 23.0 \\
\hline
\end{tabular}

The model predicts satisfactorily the cesium extraction performances based on the values obtained with the simulants. The simulants are the systems of reference since they were prepared with a series of known chemicals in carefully measured quantities. This choice was justified by the fact that the compositions of the different tanks are known less accurately. The match between the actual wastes and the simulants is also fairly good, except for the tank "post permanganate treatment." The results presented here are for a potassium concentration of $59 \mathrm{mM}$, which was revised to $40 \mathrm{mM}$ by SRS collaborators. Such a decrease leads to an increase in predicted $\mathrm{D}_{\mathrm{Cs}}$ from 8.32 to 11.7. The two tanks for which only the predictions are given exhibit the largest discrepancies. The compositions of these two tanks were provided by SRS personnel for prediction purposes alone and were not included in the original series of tests. The following section addresses some of the reasons for the discrepancies observed for some of the tanks. 


\subsection{DISCREPANCY ANALYSIS}

Although the overall predictions obtained from the model are satisfactory, some of the experimental results with the actual wastes depart not only from the prediction, but also from the distribution ratios obtained with the simulants. Since it is critical to obtain predictions as close as possible to the experimental distribution ratios, the origin of the discrepancy was investigated. Three major sources could lead to such differences: first, all of the anions present in the waste are not known, and the concentration of aluminate is used to ensure the mandatory cation/anion balance required by the computer program. This may generate some prediction error. Second, the concentration of potassium must be known with precision. The selectivity factor (i.e., $D_{\mathrm{Cs}} / D_{\mathrm{K}}$ ) for cesium over potassium is on the order of 200 for BOBCalixC6 [4], which implies that concentrations of potassium as low as a few millimolars can have a significant impact on the cesium extraction performance of the system. Third, similar concentration errors can occur for cesium and all cations may not be accounted for. This becomes an issue when assuming the presence of cations such as rubidium, for which no data has been recorded. Rubidium would interfere significantly with cesium extraction due to the poor selectivity factor $\mathrm{S}_{\mathrm{Cs} / \mathrm{Rb}}$ found for calix[4]arene crown-6 family in general [13]. Therefore, discrepancies can be due to inaccuracies in the knowledge of species concentrations in the wastes, but also to unmeasured components or components not taken into account in the model. The first two sources are investigated by varying the composition of two tank simulants, $32 \mathrm{H}$ and "post permanganate treatment". The third source requires more information and will not be studied at this time.

\subsubsection{Anion Influence}

The anion influence is studied by varying the concentration of aluminate in the system while keeping the cation/anion balance. Carbonate is chosen arbitrarily, since it is poorly extractable and very soluble. The maximum aluminate concentration is the concentration required in the simulant recipes. Four more simulants were prepared for each, where the concentration of aluminate was respectively $0 \%, 25 \%, 50 \%$, or $75 \%$ of the maximum concentration; the remaining balance was obtained, as mentioned above, with carbonate. Results are presented in Figure 1. 


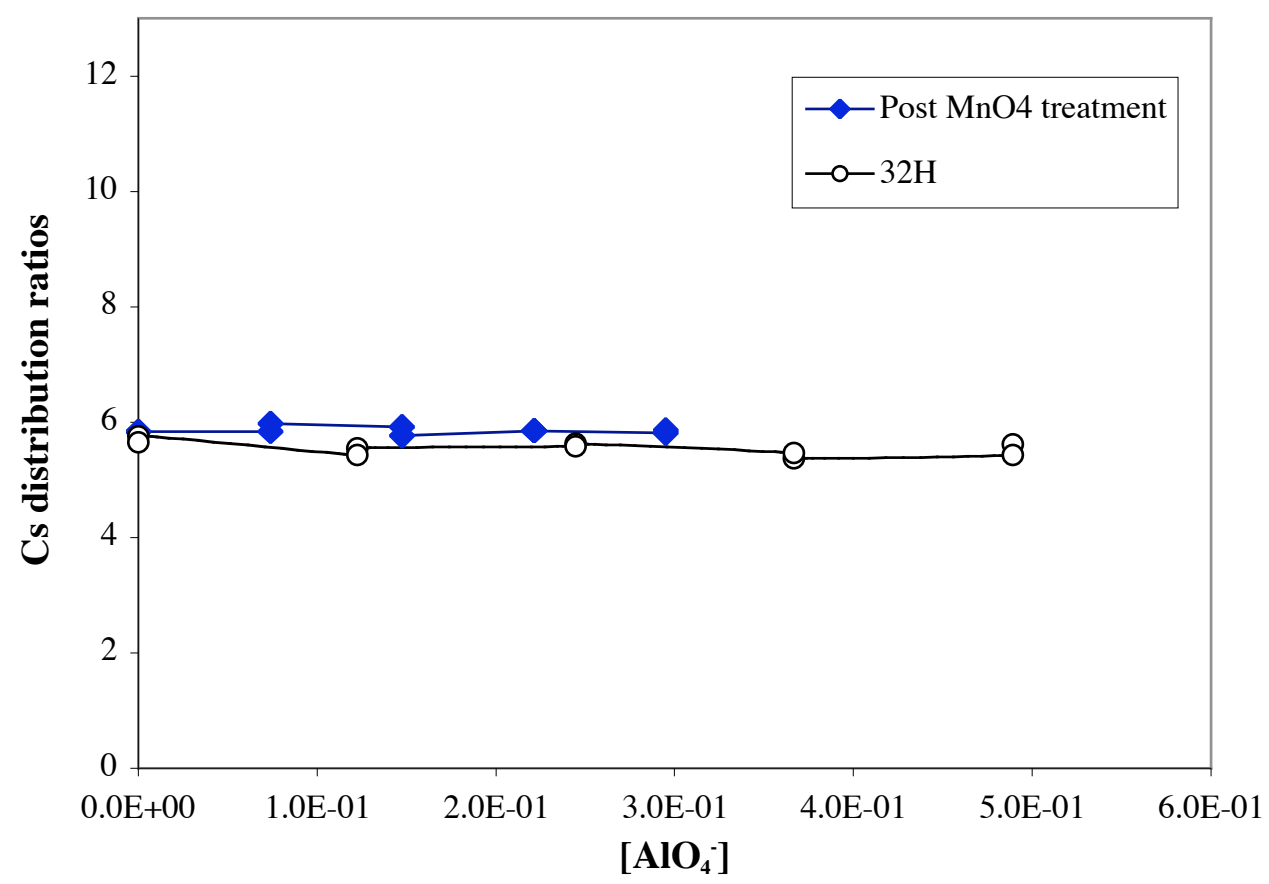

Figure 1. Influence of aluminate/carbonate ratio in tank simulant on cesium extraction

No changes in the distribution ratio values were observed. The variation of the nature of the anion has no influence on the cesium extraction performance as long as the anion is not extractable. Consolidating the nonextractable anions under the aluminate concentration in the modeling system seems then to be validated and should not generate any major changes in the predictions.

\subsubsection{Potassium Concentration Influence}

Using again the simulants of tanks $32 \mathrm{H}$ and "post permanganate treatment", the concentration of potassium was varied, and the cesium distribution ratios were obtained experimentally and predicted through modeling. As can be seen in Table 10, the potassium concentration has a significant impact on the cesium distribution ratio, and it is therefore critical to determine as accurately as possible the potassium content in a system before trying to model it. 
Table 10. Influence of potassium concentration on cesium extraction performance

\begin{tabular}{ccccc}
\hline$\left[\mathbf{K}^{+}\right]$ & \multicolumn{4}{c}{ Cesium Distribution Ratios } \\
\hline$(\mathbf{m M})$ & Simulant Post $\mathbf{M n O}_{\mathbf{4}}$ & Prediction Post MnO & Simulant 32H & Prediction 32 H \\
\hline 0 & 28.7 & 27.9 & 17.8 & 21.6 \\
20 & 14.5 & 16.1 & 11.5 & 14.0 \\
40 & 9.81 & 11.0 & 8.36 & 10.2 \\
60 & 7.66 & 8.31 & 6.94 & 8.00 \\
80 & 6.26 & 6.70 & 5.66 & 6.60 \\
100 & 5.19 & 5.59 & 4.80 & 5.61 \\
\hline
\end{tabular}

As an example, it is quite reasonable to propose that the potassium concentration in the tank "pre permanganate treatment," originally given at $5 \mathrm{mM}$, is largely underestimated, leading to an overprediction of the cesium extraction. In addition, the increase in the potassium concentration reported between the Pre- and Post- $\mathrm{MnO}_{4}$ treatment tanks suggests an error in one of the two measurements since no potassium was added during the permanganate treatment (done with less than $0.005 \mathrm{M}$ of $\mathrm{NaMnO}_{4}$ ). 


\section{CONCLUSION}

This study demonstrates that the model developed in FY2002 predicts adequately the cesium extraction performance obtained when extracting cesium from a well-defined aqueous medium with the optimized CSSX solvent. Comparison between the predicted and the actual values obtained with defined simulants showed a very good agreement. Agreement between predicted and actual values for actual waste samples was also very good, with some exceptions. Two sources of discrepancies were investigated: The first one lies in the fact that not all the anions are accounted for. The assumption that these anions are not extractable and that their concentrations can be included in the aluminate concentration was made. It was proven experimentally that varying the respective proportions of aluminate and carbonate resulted in no impact of these nonextractable anions on the cesium extraction. The second source of discrepancy pertains to the potassium concentration measured in the tanks. Fairly minor variations of this constituent in the model leads to major changes in the predicted cesium distribution ratios. That effect was demonstrated by varying the potassium concentration in a chosen simulant and using the model to predict the cesium extraction performance. The experimental and predicted values agreed, leading to the conclusion that an error on the reported potassium level in the actual waste tanks could be the source of the discrepancies. The model developed in FY2002 is therefore expected to be adequate for prediction of cesium distribution ratios, providing that the tank composition is known with fair precision and not grossly different in composition than the tested range. 


\section{REFERENCES}

1. L. H. Delmau, D. A. Bostick, T. J. Haverlock, and B. A. Moyer, Caustic-Side Solvent Extraction: Extended Equilibrium Modeling of Cesium and Potassium Distribution Behavior, ORNL/TM2002/116, Oak Ridge National Laboratory, Oak Ridge, Tennessee, May 2002.

2. L. N. Klatt, J. F. Birdwell, Jr., P. V. Bonnesen, L. H. Delmau, L. J. Foote, D. D. Lee, R. A. Leonard, T. G. Leviskaia, M. P. Maskarinec, and B. A. Moyer, Caustic-Side Solvent Extraction SolventComposition Recommendation, Report ORNL/TM-2001/258, Oak Ridge National Laboratory, Oak Ridge, TN, November 2001.

3. L.H. Delmau, T.J. Haverlock, T.G. Levitskaia, F.V. Sloop, Jr., and B.A. Moyer, Caustic-Side Solvent Extraction Chemical and Physical Properties: Equilibrium Modeling of Distribution Behavior, Report ORNL/TM-2001/267, Oak Ridge National Laboratory, Oak Ridge, TN, December 2001.

4. L. H. Delmau, J. F. Birdwell, Jr., P. V. Bonnesen, L. J. Foote, T. J. Haverlock, L. N. Klatt, D. D. Lee, R. A. Leonard, T. G. Levitskaia, M. P Maskarinec, B. A. Moyer, F. V. Sloop, Jr., and B. A. Tomkins, Caustic-Side Solvent Extraction: Chemical and Physical Properties of the Optimized Solvent, ORNL/TM-2002/190, Oak Ridge National Laboratory, Oak Ridge, Tennessee, October 2002.

5. W. R. Wilmarth, D. P. Healy, D. J. Wheeler, J. T. Mills, V. H. Dukes, D. P. DiPrete, L. H. Delmau, Caustic-Side Solvent Extraction Batch Distribution Measurements for SRS High Level Waste Samples and Dissolved Saltcake, WSRC-TR-2002-00336, Revision 1, Westinghouse Savannah River Company, Aiken, South Carolina, July 2002.

6. F. J. Milero, in Water and Aqueous Solutions, R. A. Horne, Ed., Wiley-Interscience, New York (1972).

7. K. S. Pitzer, Activity Coefficients in Electrolyte Solutions, $2^{\text {nd }}$ ed., K.S. Pitzer, Ed., CRC Press, Boca Raton (1991).

8. D.J. Wesolowski, Aluminum speciation and equilibria in aqueous solution: I. The solubility of gibbsite in the system $\mathrm{Na}-\mathrm{K}-\mathrm{Cl}-\mathrm{OH}-\mathrm{Al}(\mathrm{OH})_{4}$ from 0 to $100{ }^{\circ} \mathrm{C}$, Geochimica et Cosmochimica Acta., 26, 10651091 (1992).

9. A.R. Felmy, J.R. Rustad, M.J. Mason, and R. de la Bretonne, A Chemical Model for the Major Electrolyte Components of the Hanford Waste Tanks, PNNL Report TWRS-PP-99-090 (1994). 
10.A. F. M. Barton, Handbook of solubility parameters and other cohesion parameters, $2^{\text {nd }}$ ed., CRC Press, Boca Raton (1983).

11. Handbook of Chemistry and Physics, 57 ${ }^{\text {th }}$ ed., R. C. Weast., Ed., CRC Press, Cleveland (1976-1977).

12.C.F. Baes, Jr., Modeling Solvent Extraction Systems with SXFIT, Solvent Extr. Ion Exch., 19, 193-213 (2001).

13.C. Hill, Thèse de Doctorat de l'Université Louis Pasteur, Strasbourg, France (1994) 


\section{Appendix A}

Influence of the changes in concentrations (original values vs. revised values) on the cesium distribution ratio prediction

\begin{tabular}{lcccc}
\hline Simulant & Original value & Change & Predicted $D_{\mathrm{Cs}}$ & New Predicted $D_{\mathrm{Cs}}$ \\
\hline Tank 26F & ----- & 13.4 & 13.4 \\
Tank 34F & {$\left[\mathrm{Na}^{+}\right]=5.8 \mathrm{M}$} & {$\left[\mathrm{Na}^{+}\right]=5.94 \mathrm{M}$} & 11.0 & 10.9 \\
Tank 46F & ---- & ---- & 13.0 & 13.0 \\
Tank 30H & {$\left[\mathrm{K}^{+}\right]=40 \mathrm{mM}$} & {$\left[\mathrm{K}^{+}\right]=59 \mathrm{mM}$} & 11.2 & 8.43 \\
Tank 32H & {$\left[\mathrm{Na}^{+}\right]=5.7 \mathrm{M}$} & {$\left[\mathrm{Na}^{+}\right]=6.02 \mathrm{M}$} & 11.9 & 11.8 \\
Post $\mathrm{MnO}_{4}$ & {$\left[\mathrm{~K}^{+}\right]=59 \mathrm{mM}$} & {$\left[\mathrm{K}^{+}\right]=37 \mathrm{mM}$} & 8.43 & 11.6 \\
Tank 37H SC & {$\left[\mathrm{K}^{+}\right]=59 \mathrm{mM}$} & {$\left[\mathrm{K}^{+}\right]=39 \mathrm{mM}$} & 8.26 & 11.0 \\
& & & & \\
$41 \mathrm{H}$ & {$\left[\mathrm{Na}^{+}\right]=5.13 \mathrm{M}$} & {$\left[\mathrm{Na}^{+}\right]=6.56 \mathrm{M}$} & 6.60 & 6.33 \\
Pre $\mathrm{MnO}_{4}$ & {$\left[\mathrm{NO}_{3}^{-}\right]=0.61 \mathrm{M}$} & {$\left[\mathrm{NO}_{3}^{-}\right]=0.46 \mathrm{M}$} & 23.0 & 23.5 \\
& {$\left[\mathrm{NO}_{2}^{-}\right]=0.51 \mathrm{M}$} & {$\left[\mathrm{NO}_{2}^{-}\right]=0.39 \mathrm{M}$} & & \\
\hline
\end{tabular}




\section{INTERNAL DISTRIBUTION}

1. J. F. Birdwell, Jr.

2. P. V. Bonnesen

3. J. L. Collins

4. R. L. Cummins

5-7. L. H. Delmau

8. R. D. Hunt

9-10. T. J. Keever

11. D. D. Lee

12. A. J. Mattus

13. C. P. McGinnis

14. B. A. Moyer

15. F. V. Sloop, Jr.

16. R. D. Spence

17. B. A. Tomkins

18. J. F. Walker

19. J. S. Watson

20. ORNL Central Research Library

21. Laboratory Records, RC

22. Laboratory Records, OSTI

\section{EXTERNAL DISTRIBUTION}

23. S. G. Campbell, Westinghouse Savannah River Company, P.O. Box 616, Building 703-H, Room 107, Aiken, SC 29808

24. D. Chamberlain, Argonne National Laboratory, Building 205, 9700 South Cass Avenue, Argonne, IL 60439

25. W. D. Clark, Jr., U.S. Department of Energy, Savannah River Operations Office, Building 766-H, Aiken, SC 29808

26. C. Conner, BWX Technology, P.O. BOX 785, Lynchburg, VA 24505 
27. V. G. Dickert, Westinghouse Savannah River Company, P.O. Box 616, Building 703-H, Aiken, SC 29808

28. R. E. Edwards, Westinghouse Savannah River Company, P.O. Box 616, Building 704-3N, Aiken, SC 29808

29. S. D. Fink, Westinghouse Savannah River Company, P.O. Box 616, Building 773-A, Aiken, SC 29808

30. H. D. Harmon, Tank Focus Area Salt Processing Program, P.O. Box 616, Building 704-3N, Aiken, SC 29808

31. R. T. Jones, Westinghouse Savannah River Company, P.O. Box 616, Building 704-3N, Aiken, SC 29808

32. R. A. Leonard, Argonne National Laboratory, Building 205, 9700 South Cass Avenue, Argonne, IL 60439

33. R. K. Leugemors, Tank Focus Area Salt Processing Program, P.O. Box 616, Building 704-3N, Aiken, SC 29808

34. T. G. Levitskaia, Pacific Northwest National Laboratory, P.O. Box 999; MSIN P7-22. Richland, WA 99352

35. C. M. Maxted, Westinghouse Savannah River Company, P.O. Box 616, Building 766-H, Aiken, SC 29808

36. J. R. Noble-Dial, U.S. Department of Energy, Oak Ridge Operations Office, P.O. Box 2001, Oak Ridge, TN 37831-8620

37. Michael Norato, Westinghouse Savannah River Company, P.O. Box 616, Building 773-A, Aiken, SC 29808 
38. Robert Pierce, Westinghouse Savannah River Company, P.O. Box 616, Building 773-A, Aiken, SC 29808

39. E. Saldivar, Westinghouse Savannah River Company, P.O. Box 616, Building 766H, 2027, Aiken, SC 29808

40. S. N. Schlahta, Battelle, Pacific Northwest National Lab, P.O. Box 999 / MS K9-14 Richland, WA 99352

41. R. H. Spires, Westinghouse Savannah River Company, P.O. Box 616, Building 773-A, Aiken, SC 29808

42. P. C. Suggs, U.S. Department of Energy, Savannah River Operations Office, P.O. Box A, Building 766-H, Aiken, SC 29808

43. W. L. Tamosaitis, Westinghouse Savannah River Company, P.O. Box 616, Building 773-A, Aiken, SC 29808

44. T. A. Todd, Idaho National Engineering \& Environmental Laboratory, Building 637, MS-5218, Idaho Falls, ID 834415-5218

45. G. Vandegrift, Argonne National Laboratory, Building 205, 9700 South Cass Avenue, Argonne, IL 60439

46. D. D. Walker, Westinghouse Savannah River Company, P.O. Box 616, Building 773-A, Aiken, SC 29808

47. D. Wester, Battelle, Pacific Northwest National Lab., P.O. Box 999 / MS P7-25, Richland, WA 99352.

48. W. R. Wilmarth, Westinghouse Savannah River Company, P.O. Box 616, Building 773-A, Aiken, SC 29808 
49. Nicole Simon and Jean-François Dozol, CEA Cadarache, DESD/SEP/LPTE, Bat.326, 13108 St Paul lez Durance Cedex, France

50. Charles Madic, CEA Valrhô-Marcoule, DCC, BP 171, 30207 Bagnols s/Ceze Cedex, France 